\title{
Four gene introduction methods affect the shoot regeneration and localization of transgene expression in greenhouse stem explants and in vitro-grown chrysanthemum stem thin cell layers
}

\author{
J. A. Teixeira da Silva* and S. Fukai \\ Faculty of Agriculture, Kagawa University, Miki-cho, Kagawa, 761-0795, Japan \\ Accepted 18 April 2003
}

\begin{abstract}
Gene introduction method (GIM) affected shoot regeneration capacity (SRC) in standard and spray-type chrysanthemums. SRC was both cultivar and GIM-dependent in both in vitro and greenhouse stem explants, the former significantly higher than the latter. Sonication had an SRC-stimulating effect on in vitro explants. Other GIMs (Agrobacterium, biolistics, Agrolistics) had an SRC-inhibiting effect on greenhouse explants. Genotype-dependence of SRC was observed in both in vitro and greenhouse material. SRC is influenced by the explant and regeneration media, which should be modified if altered by the GIM. Shoots derived from all GIM treatments showed normal growth under in vitro and greenhouse conditions, and flowered normally. In addition, this study further shows that explant origin (in vitro versus greenhouse) and cultivar significantly affect the regeneration process, even when an optimized medium is utilized. The integration of the GUS transgene is also GIM-dependent, but in all cases is shown to occur in the venation.
\end{abstract}

Keywords: Agroinfection, biolistics, explant survival, regeneration, sonication.

\section{INTRODUCTION}

Chrysanthemum is the second biggest global floricultural revenue creator (2001 US market statistic). In Africa, Kenya is the fourth main floricultural exporter (ILO, 1998), with countries such as Zimbabwe, South Africa, Morocco, Uganda and Zambia also having prominent market quotas in chrysanthemum production.

A successful regeneration protocol in chrysanthemum is a prerequisite for the recovery of morphologically and developmentally normal control and transgenic plants. Any deviation from this state of optimization would hinder the efficiency of a transformation protocol. The ability to regenerate whole plants from adventitious shoots without an intermittent callus phase has been previously achieved in Dendranthema from various explant sources: leaves, stems, shoot tips, flower parts or pedicels and protoplasts (Rout and Das, 1997). It is believed that adventitious shoot regeneration derived from an initial callus phase may result however in somaclonal variation

\footnotetext{
*Corresponding Author; E-mail: jaimetex@angelfire.com, Telfax: +81878910747
}

Abbreviations: GIM, gene introduction method; SAAT, sonication-assisted Agrobacterium transformation; SRC, shoot regeneration capacity; tTCL, transverse thin cell layer.
(Larkin and Scowcroft, 1981) while direct shoot regeneration from leaf or stem explants may eliminate such an undesirable (Kaul et al., 1990). Regeneration and transformation capacity are inversely related in various Dendranthema cultivars (de Jong et al., 1993), while genotype-dependence further hinders the broad application of a single regeneration system to the genetic transformation of chrysanthemum (Teixeira da Silva and Fukai, 2002b).

In most studies on chrysanthemum, the shoot regeneration capacity (SRC) is commonly reported as the number of shoots formed per explant. This is the first report that utilizes a number of different gene introduction methods (GIMs) on various chrysanthemum cultivars to quantify the effect that GIM has on SRC in both standard and spray-type chrysanthemums. Moreover, the localization of transgene (gus) expression as affected by GIM is analyzed.

\section{MATERIALS AND METHODS}

Plant material: in vitro and greenhouse culture conditions

In vitro 'Lineker' (LIN), 'Shuhou-no-chikara' (SNC) and 'Shuhou-nokokoro' (SNK) chrysanthemum (Dendranthema X grandiflora (Ramat.) Kitamura) cultivars, the former one a spray-type, the latter two disbud-types, all autumn-flowering, were used for initial explant material. Following all GIMs, any shoots from either greenhouse or 
in vitro explants were harvested and cultured in plant boxes in vitro at a density of four plants per box on Hyponex ${ }^{\circledR}$ (soluble fertilizer, $\mathrm{N}$ : $\mathrm{P}: \mathrm{K}=6.5: 6$ : 19, $3 \mathrm{~g} / \mathrm{l}$ ) medium containing $20 \mathrm{~g} / \mathrm{l}$ sucrose. In vitro plantlets were initially acclimatized in Metromix $^{\circledR}$ soil under high relative humidity conditions, then planted in the greenhouse at a density of four plants per pot in 70:30 Masa (sandy) soil:organic compost.

\section{Explant preparation}

In vitro chrysanthemum (LIN, SNC, SNK) plantlet stem internodes were cut transversally into 300-500 $\mu \mathrm{m}$ thick transverse thin cell layers (tTCLs). Greenhouse explants (500 $\mu \mathrm{m}-1 \mathrm{~mm}$ thick) were similarly prepared after the terminal $10 \mathrm{~cm}$ of plants were harvested and surface-sterilized with a $1 \% \mathrm{NaOCl}$ solution $(1 \%$ active chlorine) for $15 \mathrm{~min}$ followed by three rinses with sterile distilled water. In vitro-derived tTCLs were placed cut surface down on optimized in vitro shoot induction medium (MSs: MS $+2 \mathrm{mg} / \mathrm{l}$ benzyladenine $(B A)+0.5 \mathrm{mg} / \mathrm{l} \alpha$-naphthalene acetic acid (NAA) + $40 \mathrm{~g} / \mathrm{l}$ sucrose) while greenhouse-derived explants were placed abaxial surface down onto optimized greenhouse explant material shoot induction medium (MSs $+1 \mathrm{mg} / \mathrm{l} \mathrm{BA}+1 \mathrm{mg} / \mathrm{l} \mathrm{NAA}+40 \mathrm{~g} / \mathrm{l}$ sucrose) and maintained under a $16 \mathrm{~h}$ photoperiod and $20 \mu \mathrm{molm}$ ${ }^{2} \mathrm{~s}^{-1}$ at $25^{\circ} \mathrm{C}$. Following a $7 \mathrm{~d}$ pre-culture period, in vitro tTCLs or greenhouse explants were subjected to the GIMs, as described in the following sections

\section{Particle bombardment}

All explants were subjected to two rounds of particle bombardment with plasmid pSKGN1 (nos promoter, nptll; 35S promoter, gus; Kirin Breweries, Inc.; structure in Teixeira da Silva and Fukai, 2002a)coated $1 \mu \mathrm{m}$ gold particles using the Bio-Rad Biolistic PDS$1000 / \mathrm{He}^{\circledR}$ particle delivery system (rupture pressure 1100 p.s.i.; target distance $6 \mathrm{~cm} ; 0.8 \mu \mathrm{g}$ plasmid DNA/500 $\mu \mathrm{g}$ Au microcarriers). Plasmid DNA was purified by the A27 small-scale method of extraction "Miniprep" (Brooks, 2003). Bombarded explants were placed onto selective (kanamycin $10 \mathrm{mg} / \mathrm{l}$ ) MSs and subcultured every 4 weeks.

\section{Agrobacterium-mediated transformation, sonication-assisted Agrobacterium-mediated transformation (SAAT) and Agrolistics}

Two different $A$. tumefaciens LBA4404 (Hoekema et al. 1983) strains, one harbouring plasmid pBI121 (nos-nptll; 35S-gus), the other pKT2 (as pSKGN1). A. tumefaciens strain LBA4404 was cultured in $20 \mathrm{ml} \mathrm{LB}$ medium for $16-20 \mathrm{~h}$ at $27^{\circ} \mathrm{C}$. One $\mathrm{ml}$ of broth culture was centrifuged, resuspended in $1 \mathrm{ml} 10 \mathrm{mM}$ glucose supplemented with $100 \mathrm{mM}$ acetosyringone and adjusted to an $\mathrm{OD}_{540}=0.4-0.5$, and applied to explants $(10-20 \mu \mathrm{l}$ per explant), which were co-cultivated for 3 or $4 \mathrm{~d}$ for in vitro or greenhouse material, respectively. SAAT explants were pre-cultured for 24-36 $\mathrm{h}$ then placed in $1.5 \mathrm{ml}$ eppendorf tubes containing $1 \mathrm{ml} 10 \mathrm{mM}$ glucose + $100 \mathrm{mM}$ acetosyringone, and sonicated at $27^{\circ} \mathrm{C}$ in a bath sonicator (luchi $^{\circledR}$ Sonicator, Japan) at $60 \mathrm{~Hz}$ for $5 \mathrm{~min}$. Following sonication, explants were blot-dried on sterilized filter paper, and placed on non-selective MSs for a $2 \mathrm{~d}$ co-culture period with LBA4404 at an $\mathrm{OD}_{540}=0.4-0.5$. Control SAAT (sonication without the presence of A. tumefaciens) were placed on non-selective $(0 \mathrm{mg} / \mathrm{l}$ kanamycin) and selective (10 mg/l kanamycin) media. Following co-cultivation (all experiments involving Agrobacterium) explants were placed on selective medium supplemented with $10 \mathrm{mg} / \mathrm{l}$ kanamycin and 250 $\mathrm{mg} / \mathrm{l}$ cefotaxime $\left(\right.$ Claforan $\left.^{\circledR}\right)$ for 1 week, then transferred onto fresh selective medium supplemented with $10 \mathrm{mg} / \mathrm{l}$ kanamycin and 125 $\mathrm{mg} / \mathrm{l}$ cefotaxime bi-monthly. Agrolistics involved the application of particle bombardment, followed by Agroinfection, in this order, and utilizing the optimized conditions specified above.

\section{Morphological scoring and histological analyses}

All explants (in vitro or greenhouse) exposed to any of the GIMs were scored for the amount of normal and deformed shoots, callus type, and explant survival after $60 \mathrm{~d}$ in culture. The SRC was quantified in this study as being stimulated when the number of normal shoots and explant survival values were high. Explants from all treatments were observed under light microscopy and scanning electron microspcopy (SEM) to observe shoot formation as well as any histological changes arising from the treatments (conditions in Teixeira da Silva and Fukai, 2002a).

DNA extraction and histological and PCR analyses of GUS positive plants

Shoots arising from explants exposed to any of the treatments (biolistics, Agroinfection, Agrolistics or SAAT) were harvested once 4-5 nodes were distinguishable, and harvested shoots were cultured on Hyponex $+20 \mathrm{~g} / \mathrm{l}$ sugar (hormone and selection-free). Shoots were considered to be totally harvested once explants died and turned black. GUS expression was measured in old (basal), middle-aged (mid-positioned) and young (terminal) leaf tissue (3 leaves from each point) from $8 \mathrm{~cm}$ shoots following incubation overnight at $37^{\circ} \mathrm{C}$ in a GUS assay (Jefferson et al., 1987). Following incubation, explants were fixed and bleached in $70 \% \mathrm{EtOH}$. The position and intensity of GUS expression was recorded.

DNA was extracted according to the CTAB method (Murray and Thompson, 1980), and the presence of the gus and nptll genes was confirmed using PCR. PCR experiments were carried out in $25 \mu \mathrm{l}$ (final volume) and performed with $\mathrm{TaKaRa}^{\circledR}$ Taq polymerase with $0.5 \mathrm{mg}$ genomic DNA samples. The synthetic oligonucleotide primer sequences GUS-1 5'-CTGTAGAAACCCCAACCCGTG-3' and B-2 5'-GCTGTGCGT AATTACCTGACCTAACC-3' amplify a 954 bp fragment containing a portion of the GUS coding region while the NP-1 5'-GAGAGGCTATTCGGCTATGA-3' and NP-2 5'GATGCTCTTCGTCCAGATCA-3' sequences amplify a 438 bp fragment containing a portion of the nptll coding region. PCR reactions were run using the TaKaRa ${ }^{\circledR}$ PCR Reagent Kit and were performed according to standard procedures in a Perkin Elmer GeneAmp PCR System $2400^{\circledR}$ thermocycler. Amplification conditions for $n p t / l$ were: $94^{\circ} \mathrm{C}$ for $5 \mathrm{~min}$, then 45 cycles $\left(94^{\circ} \mathrm{C}\right.$ for 1 $\min , 55^{\circ} \mathrm{C}$ for $1 \mathrm{~min}$ and $72^{\circ} \mathrm{C}$ for $2 \mathrm{~min}$ ), then finally $72^{\circ} \mathrm{C}$ for $10 \mathrm{~min}$ with a drop to $4^{\circ} \mathrm{C}$ until storage or utilization while those for gus were $94^{\circ} \mathrm{C}$ for $5 \mathrm{~min}$, then 50 cycles $\left(94^{\circ} \mathrm{C}\right.$ for $1 \mathrm{~min}, 50^{\circ} \mathrm{C}$ for $2 \mathrm{~min}$ and $72^{\circ} \mathrm{C}$ for $2 \mathrm{~min}$ ), then finally $72^{\circ} \mathrm{C}$ for $10 \mathrm{~min}$ with a drop to $4^{\circ} \mathrm{C}$.

\section{Flow Cytometry}

Nuclei were isolated from $0.5 \mathrm{~cm}^{2}$ of in vitro material by chopping in a few drops of Partec Buffer A (2 mM MgCl, $10 \mathrm{mM}$ Tris, $50 \mathrm{mM}$ sodium citrate, $1 \%$ PVP K-30, 0.1\% Triton-X, pH 7.5; Mishiba and Mii, 2000). Nuclear fluorescence was measured using a Partec ${ }^{\circledR}$ Ploidy Analyser (PA) after filtering the nuclear suspension through $30 \mu \mathrm{m}$ mesh size nylon filter (CellTrics ${ }^{\circledR}$ ) and adding five times of DAPI (2 mg/l 4,6-diamidino-2-phenylindole) for $1 \mathrm{~min}$. Three samples were measured for each of the GIMs and for each cultivar, and relative fluorescence intensity of the nuclei was analyzed when the coefficient of variation was $<4 \%$, with a minimum of 2500 nuclei counted for any sample.

\section{Statistical analyses}

Experiments were organized according to a complete randomized block design with three blocks of $n=20$ each per treatment (GIM) 
Table 1. Quantification of morphogenesis derived from different GIMs.

\begin{tabular}{|c|c|c|c|c|c|}
\hline \multicolumn{2}{|l|}{ Treatment } & \multicolumn{2}{|c|}{ In vitro } & \multicolumn{2}{|c|}{ Greenhouse } \\
\hline Description $n=60$ & Cv. & $\mathrm{NS} \pm \mathrm{SE}$ & $\mathrm{DS} \pm \mathrm{SE}$ & $\mathrm{NS} \pm \mathrm{SE}$ & $\mathrm{DS} \pm \mathrm{SE}$ \\
\hline Control * & $\begin{array}{l}\text { LIN } \\
\text { SNC } \\
\text { SNK }\end{array}$ & $\begin{array}{c}2.70 \pm 0.25 a \\
1.35 \pm 0.11 b c \\
1.48 \pm 0.12 b\end{array}$ & $\begin{array}{l}0.35 \pm 0.15 \mathrm{~d} \\
0.05 \pm 0.05 \mathrm{e} \\
0.15 \pm 0.08 \mathrm{e}\end{array}$ & $\begin{array}{c}1.08 \pm 0.10 \mathrm{a} \\
0.93 \pm 0.12 \mathrm{ab} \\
0.77 \pm 0.09 \mathrm{~b}\end{array}$ & $\begin{array}{c}0.45 \pm 0.17 \mathrm{~b} \\
0 \mathrm{~d} \\
0 \mathrm{~d}\end{array}$ \\
\hline Control & $\begin{array}{l}\text { LIN } \\
\text { SNC } \\
\text { SNK }\end{array}$ & $\begin{array}{l}0.35 \pm 0.06 \text { ef } \\
0.32 \pm 0.07 \text { ef } \\
0.43 \pm 0.06 \text { e }\end{array}$ & $\begin{array}{c}0.60 \pm 0.17 \mathrm{~cd} \\
0.25 \pm 0.12 \mathrm{de} \\
0.40 \pm 0.15 \mathrm{~d}\end{array}$ & $\begin{array}{l}0.47 \pm 0.06 \mathrm{c} \\
0.37 \pm 0.06 \mathrm{c} \\
0.45 \pm 0.06 \mathrm{c}\end{array}$ & $\begin{array}{c}0.80 \pm 0.17 \mathrm{a} \\
0.25 \pm 0.08 \mathrm{bc} \\
0.40 \pm 0.18 \mathrm{~b}\end{array}$ \\
\hline $\mathrm{A}-\mathrm{pBI} 121^{*}$ & $\begin{array}{l}\text { LIN } \\
\text { SNC } \\
\text { SNK }\end{array}$ & $\begin{array}{l}1.15 \pm 0.17 c \\
0.63 \pm 0.11 b \\
0.74 \pm 0.08 d\end{array}$ & $\begin{array}{l}0.10 \pm 0.07 \mathrm{e} \\
0.05 \pm 0.05 \mathrm{e} \\
0.15 \pm 0.08 \mathrm{e}\end{array}$ & $\begin{array}{c}0.28 \pm 0.06 \mathrm{~cd} \\
0 \mathrm{e} \\
0 \mathrm{e}\end{array}$ & $\begin{array}{c}0.05 \pm 0.05 \mathrm{c} \\
0 \mathrm{~d} \\
0 \mathrm{~d}\end{array}$ \\
\hline A-pKT2* & $\begin{array}{l}\text { LIN } \\
\text { SNC } \\
\text { SNK }\end{array}$ & $\begin{array}{c}0.82 \pm 0.15 \mathrm{~d} \\
0.67 \pm 0.09 \mathrm{de} \\
0.66 \pm 0.16 \mathrm{de}\end{array}$ & $\begin{array}{c}0.05 \pm 0.05 \mathrm{e} \\
0 \mathrm{e} \\
0 \mathrm{e}\end{array}$ & $\begin{array}{c}0.15 \pm 0.07 \mathrm{~d} \\
0 \mathrm{e} \\
0 \mathrm{e}\end{array}$ & $\begin{array}{c}0.05 \pm 0.05 \mathrm{c} \\
0 \mathrm{~d} \\
0 \mathrm{~d}\end{array}$ \\
\hline A-pBI121 & $\begin{array}{l}\text { LIN } \\
\text { SNC } \\
\text { SNK }\end{array}$ & $\begin{array}{l}1.07 \pm 0.13 c \\
1.40 \pm 0.15 b \\
1.60 \pm 0.13 b\end{array}$ & $\begin{array}{c}0.20 \pm 0.09 \mathrm{de} \\
0.30 \pm 0.15 \mathrm{~d} \\
0.15 \pm 0.08 \mathrm{e}\end{array}$ & $\begin{array}{l}0.58 \pm 0.08 \mathrm{bc} \\
0.23 \pm 0.06 \mathrm{~cd} \\
0.28 \pm 0.06 \mathrm{~cd}\end{array}$ & $\begin{array}{c}0.15 \pm 0.08 \mathrm{c} \\
0.05 \pm 0.05 \mathrm{~cd} \\
0.20 \pm 0.12 \mathrm{c}\end{array}$ \\
\hline A- pKT2 & $\begin{array}{l}\text { LIN } \\
\text { SNC } \\
\text { SNK }\end{array}$ & $\begin{array}{l}1.43 \pm 0.14 \mathrm{~b} \\
1.42 \pm 0.12 \mathrm{~b} \\
1.45 \pm 0.17 \mathrm{~b}\end{array}$ & $\begin{array}{l}0.10 \pm 0.07 \mathrm{e} \\
0.05 \pm 0.05 \mathrm{e} \\
0.10 \pm 0.07 \mathrm{e}\end{array}$ & $\begin{array}{c}0.33 \pm 0.07 \mathrm{~cd} \\
0.25 \pm 0.06 \mathrm{~cd} \\
0.40 \pm 0.08 \mathrm{c}\end{array}$ & $\begin{array}{c}0.05 \pm 0.05 \mathrm{~cd} \\
0.20 \pm 0.20 \mathrm{c} \\
0 \mathrm{~d}\end{array}$ \\
\hline B-Cont-Au only * & $\begin{array}{l}\text { LIN } \\
\text { SNC } \\
\text { SNK }\end{array}$ & $\begin{array}{c}0.78 \pm 0.10 \mathrm{~d} \\
0.22 \pm 0.09 \mathrm{fg} \\
0.40 \pm 0.08 \mathrm{e}\end{array}$ & $\begin{array}{c}0.70 \pm 0.16 \mathrm{c} \\
0.40 \pm 0.13 \mathrm{~d} \\
0.25 \pm 0.20 \mathrm{de}\end{array}$ & $\begin{array}{c}0.35 \pm 0.08 \mathrm{~cd} \\
0.32 \pm 0.08 \mathrm{~cd} \\
0.17 \pm 0.05 \mathrm{~d}\end{array}$ & $\begin{array}{c}0.05 \pm 0.05 \mathrm{~cd} \\
0.30 \pm 0.13 \mathrm{bc} \\
0.15 \pm 0.11 \mathrm{c}\end{array}$ \\
\hline B-pSKGN1 & $\begin{array}{l}\text { LIN } \\
\text { SNC } \\
\text { SNK }\end{array}$ & $\begin{array}{c}0.50 \pm 0.11 \mathrm{e} \\
0.17 \pm 0.05 \mathrm{fg} \\
0.40 \pm 0.08 \mathrm{e}\end{array}$ & $\begin{array}{l}0.55 \pm 0.15 \mathrm{~d} \\
0.35 \pm 0.11 \mathrm{~d} \\
0.35 \pm 0.13 \mathrm{~d}\end{array}$ & $\begin{array}{c}0.38 \pm 0.06 \mathrm{~cd} \\
0.23 \pm 0.06 \mathrm{~cd} \\
0.17 \pm 0.05 \mathrm{~d}\end{array}$ & $\begin{array}{c}0 \mathrm{~d} \\
0.05 \pm 0.05 \mathrm{~cd} \\
0 \mathrm{~d}\end{array}$ \\
\hline SAAT-Cont * & $\begin{array}{l}\text { LIN } \\
\text { SNC } \\
\text { SNK }\end{array}$ & $\begin{array}{l}0.25 \pm 0.06 \mathrm{f} \\
2.93 \pm 0.34 \mathrm{a} \\
2.77 \pm 0.33 \mathrm{a}\end{array}$ & $\begin{array}{l}1.05 \pm 0.37 \mathrm{~b} \\
1.70 \pm 0.41 \mathrm{a} \\
1.85 \pm 0.44 \mathrm{a}\end{array}$ & $\begin{array}{l}0 \mathrm{e} \\
0 \mathrm{e} \\
0 \mathrm{e}\end{array}$ & $\begin{array}{c}0.05 \pm 0.05 \mathrm{~cd} \\
0 \mathrm{~d} \\
0 \mathrm{~d}\end{array}$ \\
\hline SAAT-Cont-Kan-10 & $\begin{array}{l}\text { LIN } \\
\text { SNC } \\
\text { SNK }\end{array}$ & $\begin{array}{l}0.15 \pm 0.08 \mathrm{~g} \\
0.70 \pm 0.16 \mathrm{~d} \\
0.70 \pm 0.18 \mathrm{~d}\end{array}$ & $\begin{array}{c}0.55 \pm 0.11 \mathrm{~d} \\
0.60 \pm 0.11 \mathrm{~cd} \\
0.80 \pm 0.20 \mathrm{bc}\end{array}$ & $\begin{array}{l}0 \mathrm{e} \\
0 \mathrm{e} \\
0 \mathrm{e}\end{array}$ & $\begin{array}{l}0 \mathrm{~d} \\
0 \mathrm{~d} \\
0 \mathrm{~d}\end{array}$ \\
\hline SAAT-pBI121 & $\begin{array}{l}\text { LIN } \\
\text { SNC } \\
\text { SNK }\end{array}$ & $\begin{array}{l}0.15 \pm 0.05 \mathrm{~g} \\
0.60 \pm 0.09 \mathrm{e} \\
0.85 \pm 0.12 \mathrm{~d}\end{array}$ & $\begin{array}{c}0.70 \pm 0.13 \mathrm{c} \\
0.60 \pm 0.17 \mathrm{~cd} \\
0.70 \pm 0.27 \mathrm{c}\end{array}$ & $\begin{array}{l}0 \mathrm{e} \\
0 \mathrm{e} \\
0 \mathrm{e}\end{array}$ & $\begin{array}{c}0.15 \pm 0.08 \mathrm{c} \\
0 \mathrm{~d} \\
0.05 \pm 0.05 \mathrm{~cd}\end{array}$ \\
\hline SAAT-pKT2 & $\begin{array}{l}\text { LIN } \\
\text { SNC } \\
\text { SNK }\end{array}$ & $\begin{array}{c}0.28 \pm 0.08 \mathrm{f} \\
0.40 \pm 0.09 \mathrm{e} \\
0.68 \pm 0.14 \mathrm{de}\end{array}$ & $\begin{array}{c}0.55 \pm 0.26 \mathrm{~cd} \\
0.65 \pm 0.28 \mathrm{c} \\
0.80 \pm 0.31 \mathrm{bc}\end{array}$ & $\begin{array}{l}0 \mathrm{e} \\
0 \mathrm{e} \\
0 \mathrm{e}\end{array}$ & $\begin{array}{c}0.15 \pm 0.08 \mathrm{c} \\
0 \mathrm{~d} \\
0 \mathrm{~d}\end{array}$ \\
\hline AB-Au-pBI121 & $\begin{array}{l}\text { LIN } \\
\text { SNC } \\
\text { SNK }\end{array}$ & $\begin{array}{c}1.22 \pm 0.13 \mathrm{c} \\
0.43 \pm 0.11 \mathrm{e} \\
0.65 \pm 0.15 \mathrm{de}\end{array}$ & $\begin{array}{c}0.25 \pm 0.12 \mathrm{de} \\
0.10 \pm 0.07 \mathrm{e} \\
0.20 \pm 0.09 \mathrm{de}\end{array}$ & $\begin{array}{l}0 \mathrm{e} \\
0 \mathrm{e} \\
0 \mathrm{e}\end{array}$ & $\begin{array}{l}0.10 \pm 0.07 \mathrm{~cd} \\
0.05 \pm 0.05 \mathrm{~cd} \\
0.05 \pm 0.05 \mathrm{~cd}\end{array}$ \\
\hline AB-Au- pKT2 & $\begin{array}{l}\text { LIN } \\
\text { SNC } \\
\text { SNK }\end{array}$ & $\begin{array}{c}1.50 \pm 0.23 \mathrm{~b} \\
0.27 \pm 0.11 \mathrm{f} \\
0.30 \pm 0.08 \text { ef }\end{array}$ & $\begin{array}{c}0.35 \pm 0.13 \mathrm{~d} \\
0.25 \pm 0.18 \mathrm{de} \\
0.30 \pm 0.11 \mathrm{~d}\end{array}$ & $\begin{array}{l}0 \mathrm{e} \\
0 \mathrm{e} \\
0 \mathrm{e}\end{array}$ & $\begin{array}{l}0.10 \pm 0.07 \mathrm{~cd} \\
0.10 \pm 0.07 \mathrm{~cd} \\
0.10 \pm 0.07 \mathrm{~cd}\end{array}$ \\
\hline AB-pKT2-pBI121 & $\begin{array}{l}\text { LIN } \\
\text { SNC } \\
\text { SNK }\end{array}$ & $\begin{array}{l}0.40 \pm 0.13 \mathrm{e} \\
1.10 \pm 0.29 \mathrm{c} \\
0.55 \pm 0.26 \mathrm{e}\end{array}$ & $\begin{array}{c}0.25 \pm 0.10 \mathrm{de} \\
0.65 \pm 0.25 \mathrm{c} \\
0.65 \pm 0.32 \mathrm{c}\end{array}$ & $\begin{array}{l}0 \mathrm{e} \\
0 \mathrm{e} \\
0 \mathrm{e}\end{array}$ & $\begin{array}{l}0 d \\
0 d \\
0 d\end{array}$ \\
\hline AB-pKT2-pSKGN1 & $\begin{array}{l}\text { LIN } \\
\text { SNC } \\
\text { SNK }\end{array}$ & $\begin{array}{l}0.60 \pm 0.26 \mathrm{e} \\
1.25 \pm 0.32 \mathrm{c} \\
0.45 \pm 0.15 \mathrm{e}\end{array}$ & $\begin{array}{l}0.35 \pm 0.13 d \\
0.65 \pm 0.26 c \\
0.75 \pm 0.29 c\end{array}$ & $\begin{array}{l}0 \mathrm{e} \\
0 \mathrm{e} \\
0 \mathrm{e}\end{array}$ & $\begin{array}{l}0.05 \pm 0.05 \mathrm{~cd} \\
0.10 \pm 0.07 \mathrm{~cd} \\
0.05 \pm 0.05 \mathrm{~cd}\end{array}$ \\
\hline
\end{tabular}

$\mathrm{A}=$ Agroinfection; $\mathrm{B}=\mathrm{Bombardment;} \mathrm{SAAT}=$ Sonication-assisted Agrobacterium trans- formation; AB=Agrolistics (AxB); Cont=Control; $A$ u=Gold; LIN='Lineker'; SNC= 'Shuhou-no-chikara'; SNK='Shuhou-no-kokoro'; NS=Number of normal shoots; DS= Number of deformed shoots (hyperhydric, bleached or abnormal morphology); all treatments are kanamycin $10 \mathrm{mg} / \mathrm{l}$ except for ${ }^{*}=$ kanamycin $0 \mathrm{mg} / \mathrm{l}$; different letters within a column indicate significant differences $(P=0.05)$ using Duncan's Multiple Range test.

per cultivar. Data was analysed for significance $(P=0.05)$ by ANOVA with the mean separation by Duncan's New Multiple Range test (DMRT).

\section{RESULTS}

\section{Effect of GIM on shoot formation}

Shoot regeneration capacity (SRC) is cultivar-dependent, with an average of $2.70,1.35$ and 1.48 adventitious shoots (Figure $1 \mathrm{H}$ ) obtained from in vitro LIN, SNC and SNK stem tTCLs, respectively when on a non-selective medium. This SRC is significantly reduced to $0.35,0.32$ and 0.43 shoots per explant when on a $10 \mathrm{mg} / \mathrm{l}$ kanamycin selection medium (Table 1) but not so when grown only on a cefotaxime-supplemented medium (Teixeira da Silva and Fukai, 2001). SRC decreases with any GIM with a subsequent increase in the number of 


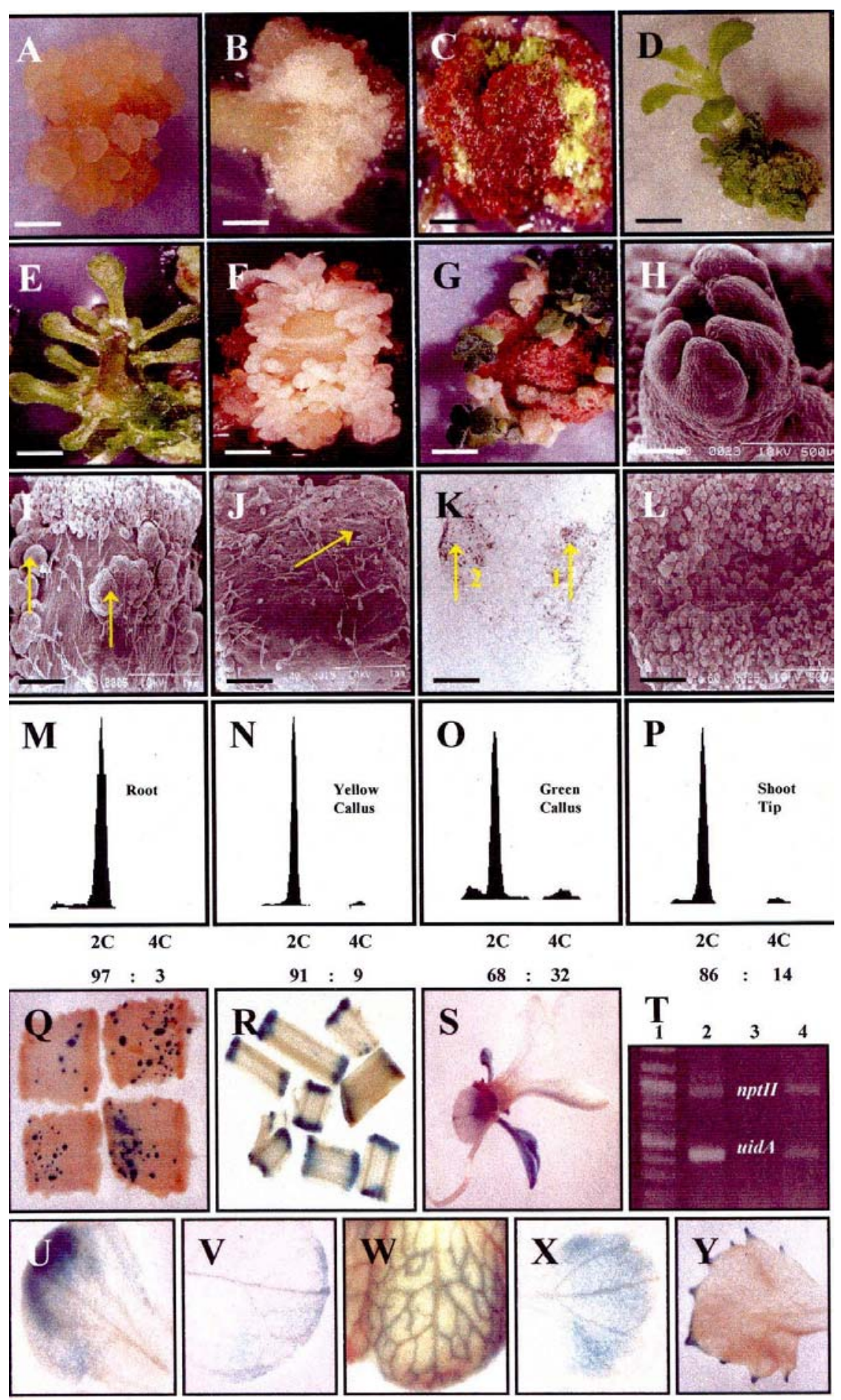

Figure 1. In vitro growth reaction of 'Shuhou-no-chikara' chrysanthemum. A)-F) In vitro explants. A) Yellow, embryogenic callus; B) White, friable callus; C) Red, friable callus; D) Caulo- and callogenesis from a single explant; E) Deformed, hyperhydric shoot; F) Bleached control shoot primordia in reaction to $10 \mathrm{mg} / \mathrm{l}$ kanamycin-supplemented medium; G) Caulogenesis from greenhouse stem explant; $\mathrm{H}$ ) SEM of young shoot; I) Emergence of shoot primordia (arrows) in reaction to particle bombardment; J) Fissures (arrow) created by sonication; K) Shoot emergence from original explant cortex ( $\uparrow 1)$, and callus from epidermal and subepidermal layers ( $\uparrow 2)$; L) Profuse callogenesis on cut surface in contact with medium. Representative histograms of root $(\mathrm{M}, \mathrm{CV}=2.4 \%)$, yellow callus $(\mathrm{N}, \mathrm{CV}=3,7 \%)$, green callus $(\mathrm{O}, \mathrm{CV}=2.9 \%)$ and shoot tip $(\mathrm{P}, \mathrm{CV}=3.1 \%)$ of in vitro material showing relative $2 \mathrm{C}: 4 \mathrm{C}$ ratios (other smaller peaks not considered). GIMs: particle bombardment with pSKGN1 (Q), Agroinfection with pKT2 (R). Genetic transformant (S) confirmed by PCR (T): lane 1 (size marker), lane 2 (positive control, purified pSKGN1from LBA4404), upper band = GUS (954 bp), lower band = nptII (438 bp), lane 3 (negative control, in vitro LIN), lane 4 (positive transformant, in vitro LIN). Transgene (GUS) expression patterns: epidermis (U), leaf edge (V), venation (W), intervein (X), leaf tips (Y). Bars: $100 \mu \mathrm{m}(\mathrm{K}), 200 \mu \mathrm{m}(\mathrm{A}, \mathrm{B}, \mathrm{H}, \mathrm{L}), 300 \mu \mathrm{m}$ (C, F, I, J) and $400 \mu \mathrm{m}(\mathrm{D}, \mathrm{E}, \mathrm{G})$. 
deformed shoots, except for sonication (Table 1, Figure $1 \mathrm{E}-\mathrm{G})$. Although greenhouse explants had a significantly lower SRC than in vitro tTCLs on a non-selective medium (1.08, 0.93 and 0.77 for LIN, SNC and SNK, respectively; Table 1), the SRC was not significantly different when on selective medium $(0.47,0.37$ and 0.45 for LIN, SNC and SNK, respectively; Table 1).

In vitro controls of all cultivars, when on a non-selective medium showed high number of normal shoots and few deformed shoots (Table 1) and a $100 \%$ explant survival, these levels inverting when control explants were placed onto selective medium (i.e. a decrease in the SRC of explants).

Bombardment of in vitro tTCLs decreased the SRC (except for LIN) and did not stimulate the formation of normal shoots, controls having a higher percentage of explant necrosis $(100 \%$ - explant survival) than no treatment controls (Table 1). In contrast bombardment of greenhouse explants with or without plasmid coating inhibited SRC.

In SAAT controls of both in vitro and greenhouse material, there was an increase in both the amount of normal and deformed shoots (Table 1), without a great decrease in explant survival (Figure 2A,B). In greenhouse controls (Table 1), the number of normal shoots decreased significantly. SRC was enhanced by SAAT in SNC and SNK in in vitro tTCLs but decreased in LIN. SAAT, together with antibiotic selection, resulted in high in vitro tTCL mortality with a low normal shoot formation (Table 1).

A. tumefaciens (either plasmid construct \pm kanamycin) had a negative impact on the SRC of both in vitro and greenhouse explants (Table 1). When greenhouse explants were used, Agroinfection decreased the number of normal shoots formed. SAAT (with Agrobacterium) of greenhouse explants completely inhibited normal shoot formation (Table 1).

Agrolistics increased the SRC in in vitro tTCLs with a relatively high explant survival. Agrolistics positively impacted the SRC in in vitro tTCLs of all genotypes (Table 1), the increase in the number of normal shoots accentuated in LIN when only Au particles were used, as opposed to plasmid-coated $\mathrm{Au}$ particles in SNC. Agrolistics of greenhouse explants completely inhibited normal shoot formation, despite a high explant survival (Table 1, Figure 2A,B).

\section{Effect of GIM on callus formation}

The reduction in SRC observed when tTCLs were placed on a selection medium was associated with the formation of yellow, embryogenic-like callus, primarily on in vitro tTCLs (Figure 1A, 2A), and in a $100 \%$ explant survival (Figure 2A,B). Greenhouse-derived explants from any cultivar show significantly greater levels of callus formation than in vitro tTCLs (Figure 1C, 2B). The transfer of any callus type (green, yellow, white, red) onto optimized shoot regeneration medium (MSs) under differing light intensities revealed that only green (Figure 1D) and white callus (Figure 1B) had a shoot or callus regeneration potential, but yellow (Figure $1 \mathrm{~A}$ ) and red callus (Figure 1C) both became necrotic over time.

Bombardment of in vitro or greenhouse tTCLs stimulated the amount of red and yellow or white and red callus formed, respectively (Table 1, Figure 2A,B).

SAAT of in vitro explants with selection had increased yellow callus formation. In greenhouse controls (Table 1), predominantly green callus without selection, and yellow callus with selection could be observed (Figure 2B). SAAT, together with antibiotic selection, resulted in only the formation of yellow callus (Table 1). SAAT (with $A$. tumefaciens: either plasmid construct \pm kanamycin) of greenhouse explants led to a high level of red callus formation (Figure 2B), despite a high explant survival (Figure 2A,B).

Agrolistics of in vitro tTCLs resulted in low levels of any callus formation (Figure 2A), but that of greenhouse explants led to a high level of red callus formation (Figure 2B).

\section{Effect of GIM on ploidy stability}

Flow cytometry results (Figure $1 \mathrm{M}-\mathrm{P}$ ) indicate a high level of genetic stability in initial explant and regenerated tissue (callus or shoot) without a divergence from the diploid state, and no endoreduplication was registered. $G_{0} / G_{1}: G_{2}$ ratios from callus or shoots differed between GIMs, but the same callus type (green, yellow, white or red) from different GIMs had similar ratios. Actively-growing callus (green and white callus) had lower $\mathrm{G}_{0} / \mathrm{G}_{1}: \mathrm{G}_{2}$ ratios than red or yellow callus. Shoots from any GIM had intermediate $G_{0} / G_{1}: G_{2}$ ratios, which varied little between in vitro and greenhouse material.

\section{Transgene expression}

No GUS activity could be observed for any control plants at any selection level for both in vitro or greenhouse material. In in vitro LIN, GUS activity could be observed in young, middle-aged and old leaves (Table 2). This activity could be detected whether Agroinfection was with pBI121 or pKT2, but higher when pBI121 was used. Even though GUS expression could be observed in all tissues types, the predominant tissue of expression was veins and mid-rib with pBI121 and mid-rib with pKT2 (Figure 1). In greenhouse LIN, however, there is a distinct increase in observable GUS activity from apex (young leaves) to base (old leaves). The mid-rib and vein were also the predominant GUS positively stained tissue for both pBI121 and pKT2. In vitro SNC was only Agroinfected by $\mathrm{pB} \mid 121$, and even so, only in old leaves, giving rise to a 

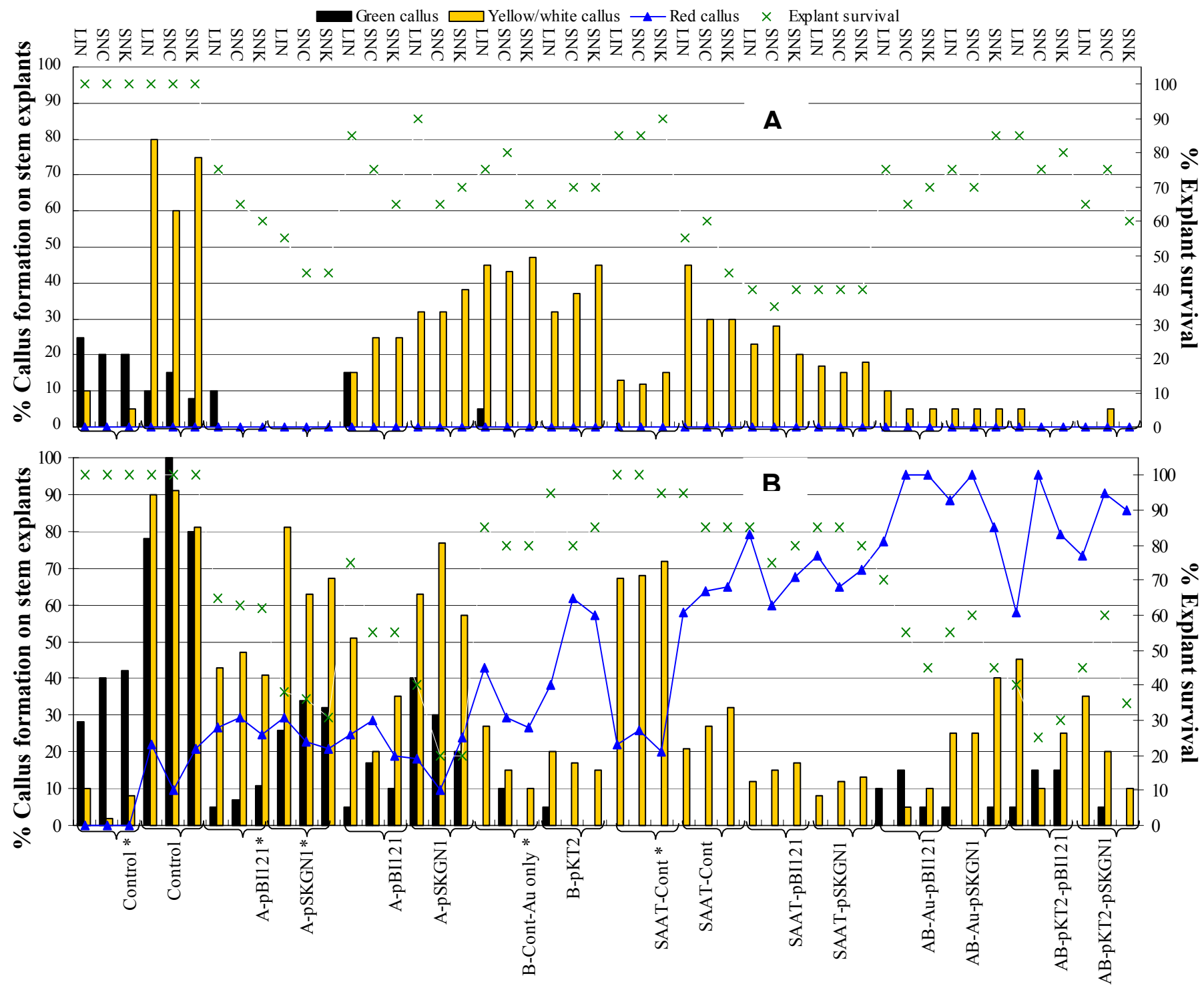

GIM treatment

Figure 2. Reaction of in vitro and greenhouse explants from all three cultivars exposed to different GIM treatments (48 in total, $x$-axis corresponding to treatment numbers in Table 1). Callus types (absolute percentages) formed on in vitro (A) and greenhouse explants (B)

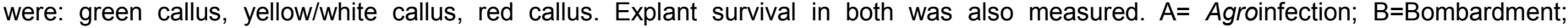
$\mathrm{SAAT}=$ Sonication-assisted Agrobacterium transformation; $\mathrm{AB}=$ Agrolistics (AxB); Cont=Control; Au=Gold; LIN='Lineker'; SNC= 'Shuhou-nochikara'; SNK='Shuhou-no-kokoro'; all treatments are kanamycin $10 \mathrm{mg} / \mathrm{l}$ except for * = kanamycin $0 \mathrm{mg} / \mathrm{l}$.

GUS expression pattern only in leaf tips. In greenhousederived material, in vitro transformants (Figure 1S) showed GUS expression only in the veins of old leaves when pBI121 was used. With pSKGN1, however, there was a gradient of GUS expression with plant tissue age, maximum in the old leaves, with a majority GUS expression in mid-ribs and veins. In vitro SNK was not Agroinfected with either pBI121 or pKT2. Greenhouse material was however prone to strong Agroinfection by both pBI121 and pKT2, exhibiting similar GUSexpression-plantlet-age relationships as described above, and having a dominant mid-rib and vein expression. Particle bombardment of any plant with non DNA-coated microprojectiles produced no GUS staining. When pKT2 was used, however, GUS staining could only be observed in LIN and SNC in vitro plant leaf tissue. In both, a high frequency of GUS expression occurred in old leaves, with expression primarily in the veins and mid-rib. GUS expression could be observed in all tissue types, except for SNC. In sonication treatments in which Agrobacterium was not used (SAAT-no Agro), on either selective or non-selective medium, GUS expression 
Table 2. GUS positive shoot quantification and staining localization in various treatments for different cultivars.

\begin{tabular}{|c|c|c|c|c|c|c|c|c|c|c|c|c|c|c|c|c|c|c|c|}
\hline Treatment $(n=60)$ & Cultivar & \multicolumn{9}{|c|}{ In vitro } & \multicolumn{9}{|c|}{ Greenhouse } \\
\hline & & $\mathbf{Y}$ & $\mathbf{M}$ & 0 & $I^{t}$ & $v^{t}$ & $\mathrm{mr}^{\mathrm{t}}$ & $1 e^{t}$ & $\overline{i v^{\mathbf{t}}}$ & $e^{t}$ & $\bar{Y}$ & $\mathbf{M}$ & 0 & $\mid \mathbf{I t}^{\mathrm{t}}$ & $v^{t}$ & $\mathrm{mr}^{\mathrm{t}}$ & $1 e^{t}$ & iv $^{t}$ & $e^{t}$ \\
\hline C- 0, C- -10, C- 25, C-50 & $\begin{array}{l}\text { Lineker } \\
\text { SNC } \\
\text { SNK }\end{array}$ & - & $\begin{array}{l}- \\
-\end{array}$ & 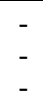 & $\overline{-}$ & $\overline{-}$ & $\overline{-}$ & $\begin{array}{l}- \\
-\end{array}$ & $\begin{array}{l}- \\
-\end{array}$ & $\bar{z}$ & $\begin{array}{l}- \\
-\end{array}$ & $\begin{array}{l}- \\
-\end{array}$ & $\begin{array}{l}- \\
-\end{array}$ & $\begin{array}{l}- \\
-\end{array}$ & $\begin{array}{l}- \\
-\end{array}$ & 5 & $\begin{array}{l}- \\
-\end{array}$ & $\begin{array}{l}- \\
-\end{array}$ & $\begin{array}{l}- \\
-\end{array}$ \\
\hline A-pBI121 & $\begin{array}{l}\text { Lineker } \\
\text { SNC } \\
\text { SNK }\end{array}$ & $\begin{array}{c}13 \\
-\end{array}$ & 10 & $\begin{array}{c}13 \\
3\end{array}$ & $\begin{array}{l}6 \\
3\end{array}$ & $\begin{array}{c}25 \\
-\end{array}$ & $\begin{array}{c}19 \\
-\end{array}$ & $\begin{array}{l}3 \\
-\end{array}$ & $\begin{array}{l}2 \\
-\end{array}$ & $\begin{array}{l}5 \\
-\end{array}$ & $\begin{array}{l}1 \\
- \\
6\end{array}$ & $\begin{array}{c}2 \\
- \\
11\end{array}$ & $\begin{array}{c}9 \\
2 \\
12 \\
\end{array}$ & $\begin{array}{l}3 \\
- \\
- \\
\end{array}$ & $\begin{array}{l}4 \\
2 \\
5 \\
\end{array}$ & $\begin{array}{c}1 \\
- \\
11 \\
\end{array}$ & $\begin{array}{l}3 \\
- \\
- \\
\end{array}$ & $\begin{array}{l}1 \\
- \\
- \\
\end{array}$ & $\begin{array}{l}4 \\
- \\
2\end{array}$ \\
\hline A-pKT2 & $\begin{array}{l}\text { Lineker } \\
\text { SNC } \\
\text { SNK }\end{array}$ & $\begin{array}{l}1 \\
- \\
- \\
\end{array}$ & $\begin{array}{l}1 \\
- \\
-\end{array}$ & $\begin{array}{l}6 \\
- \\
- \\
\end{array}$ & $\begin{array}{c}10 \\
- \\
-\end{array}$ & $\begin{array}{l}7 \\
- \\
- \\
\end{array}$ & $\begin{array}{l}13 \\
- \\
-\end{array}$ & $\begin{array}{l}10 \\
- \\
- \\
\end{array}$ & $\begin{array}{l}3 \\
- \\
-\end{array}$ & $\begin{array}{l}10 \\
- \\
-\end{array}$ & $\begin{array}{l}3 \\
1 \\
5 \\
\end{array}$ & $\begin{array}{l}5 \\
2 \\
7 \\
\end{array}$ & $\begin{array}{c}11 \\
4 \\
4 \\
\end{array}$ & $\begin{array}{l}6 \\
2 \\
1 \\
\end{array}$ & $\begin{array}{c}7 \\
6 \\
21 \\
\end{array}$ & $\begin{array}{c}6 \\
4 \\
28 \\
\end{array}$ & $\begin{array}{l}7 \\
1 \\
1 \\
\end{array}$ & $\begin{array}{l}3 \\
- \\
- \\
\end{array}$ & $\begin{array}{l}9 \\
- \\
2\end{array}$ \\
\hline B-No plasmid & $\begin{array}{l}\text { Lineker } \\
\text { SNC } \\
\text { SNK } \\
\end{array}$ & - & - & - & $\begin{array}{l}- \\
-\end{array}$ & $\overline{-}$ & - & - & $\begin{array}{l}- \\
- \\
-\end{array}$ & $\begin{array}{l}- \\
- \\
-\end{array}$ & $\begin{array}{l}- \\
- \\
-\end{array}$ & $\begin{array}{l}- \\
- \\
- \\
\end{array}$ & $\begin{array}{l}- \\
- \\
- \\
\end{array}$ & $\begin{array}{l}- \\
- \\
- \\
\end{array}$ & $\begin{array}{l}- \\
- \\
- \\
\end{array}$ & $\begin{array}{l}- \\
- \\
-\end{array}$ & $\begin{array}{l}- \\
- \\
- \\
\end{array}$ & $\begin{array}{l}- \\
- \\
- \\
\end{array}$ & - \\
\hline B-pSKGN1 & $\begin{array}{l}\text { Lineker } \\
\text { SNC } \\
\text { SNK }\end{array}$ & $\begin{array}{c}16 \\
-\end{array}$ & $\begin{array}{c}22 \\
-\end{array}$ & $\begin{array}{c}74 \\
1\end{array}$ & $\begin{array}{c}28 \\
-\end{array}$ & $\begin{array}{c}64 \\
1\end{array}$ & $\begin{array}{c}12 \\
1\end{array}$ & $\begin{array}{c}15 \\
-\end{array}$ & $\begin{array}{l}3 \\
- \\
-\end{array}$ & $\begin{array}{c}21 \\
1\end{array}$ & - & - & $\begin{array}{l}- \\
-\end{array}$ & $\begin{array}{l}- \\
- \\
-\end{array}$ & $\begin{array}{l}- \\
- \\
-\end{array}$ & - & $\begin{array}{l}- \\
- \\
-\end{array}$ & $\begin{array}{l}- \\
- \\
-\end{array}$ & - \\
\hline SAAT-no Agro* or +K10* & $\begin{array}{l}\text { Lineker } \\
\text { SNC } \\
\text { SNK }\end{array}$ & $\begin{array}{l}- \\
- \\
-\end{array}$ & $\begin{array}{l}- \\
- \\
-\end{array}$ & - & $\begin{array}{l}- \\
- \\
-\end{array}$ & $\begin{array}{l}- \\
- \\
-\end{array}$ & $\begin{array}{l}- \\
- \\
-\end{array}$ & $\begin{array}{l}- \\
- \\
-\end{array}$ & $\begin{array}{l}- \\
- \\
-\end{array}$ & $\begin{array}{l}- \\
- \\
-\end{array}$ & & & & & $\begin{array}{l}\text { n.a } \\
\text { n.a } \\
\text { n.a }\end{array}$ & & & & \\
\hline SAAT-pBI121* & $\begin{array}{l}\text { Lineker } \\
\text { SNC } \\
\text { SNK } \\
\end{array}$ & $\begin{array}{l}1 \\
- \\
-\end{array}$ & $\begin{array}{l}8 \\
1 \\
- \\
\end{array}$ & $\begin{array}{c}15 \\
2 \\
- \\
\end{array}$ & $\begin{array}{c}17 \\
3 \\
- \\
\end{array}$ & $\begin{array}{l}3 \\
- \\
- \\
\end{array}$ & $\begin{array}{l}1 \\
- \\
- \\
\end{array}$ & $\begin{array}{c}14 \\
1 \\
- \\
\end{array}$ & $\begin{array}{l}1 \\
- \\
-\end{array}$ & $\begin{array}{c}12 \\
- \\
- \\
\end{array}$ & & & & & $\begin{array}{l}\text { n.a } \\
\text { n.a } \\
\text { n.a }\end{array}$ & & & & \\
\hline SAAT-pKT2* & $\begin{array}{l}\text { Lineker } \\
\text { SNC } \\
\text { SNK }\end{array}$ & $\begin{array}{l}2 \\
- \\
-\end{array}$ & $\begin{array}{l}5 \\
- \\
-\end{array}$ & $\begin{array}{c}23 \\
- \\
-\end{array}$ & $\begin{array}{l}9 \\
- \\
-\end{array}$ & $\begin{array}{l}1 \\
- \\
-\end{array}$ & $\begin{array}{l}2 \\
- \\
-\end{array}$ & $\begin{array}{c}19 \\
- \\
-\end{array}$ & $\begin{array}{l}2 \\
- \\
-\end{array}$ & $\begin{array}{c}17 \\
- \\
-\end{array}$ & & & & & $\begin{array}{l}\text { n.a } \\
\text { n.a } \\
\text { n.a }\end{array}$ & & & & \\
\hline AB-Nopl+pBI121 & $\begin{array}{l}\text { Lineker } \\
\text { SNC } \\
\text { SNK } \\
\end{array}$ & $\begin{array}{l}2 \\
- \\
- \\
\end{array}$ & $\begin{array}{l}4 \\
1\end{array}$ & $\begin{array}{c}17 \\
1\end{array}$ & $\begin{array}{c}13 \\
1\end{array}$ & $\begin{array}{l}9 \\
1\end{array}$ & $\begin{array}{l}9 \\
-\end{array}$ & $\begin{array}{c}17 \\
- \\
- \\
\end{array}$ & $\begin{array}{l}9 \\
- \\
- \\
\end{array}$ & $\begin{array}{c}13 \\
- \\
- \\
\end{array}$ & $\begin{array}{l}- \\
- \\
-\end{array}$ & $\begin{array}{l}- \\
- \\
- \\
\end{array}$ & $\begin{array}{l}- \\
- \\
- \\
\end{array}$ & $\begin{array}{l}- \\
- \\
- \\
\end{array}$ & $\begin{array}{l}- \\
- \\
- \\
\end{array}$ & $\begin{array}{l}- \\
- \\
-\end{array}$ & $\begin{array}{l}- \\
- \\
- \\
\end{array}$ & $\begin{array}{l}- \\
- \\
- \\
\end{array}$ & - \\
\hline AB-Nopl+pKT2 & $\begin{array}{l}\text { Lineker } \\
\text { SNC } \\
\text { SNK }\end{array}$ & $\begin{array}{l}- \\
- \\
-\end{array}$ & $\begin{array}{l}3 \\
- \\
-\end{array}$ & $\begin{array}{c}15 \\
3 \\
-\end{array}$ & $\begin{array}{l}8 \\
5 \\
-\end{array}$ & $\begin{array}{c}6 \\
10 \\
-\end{array}$ & $\begin{array}{l}6 \\
5 \\
-\end{array}$ & $\begin{array}{l}9 \\
6 \\
-\end{array}$ & $\begin{array}{l}6 \\
- \\
-\end{array}$ & $\begin{array}{l}14 \\
- \\
-\end{array}$ & $\begin{array}{l}- \\
- \\
-\end{array}$ & $\begin{array}{l}- \\
- \\
-\end{array}$ & $\begin{array}{l}- \\
- \\
-\end{array}$ & $\begin{array}{l}- \\
- \\
-\end{array}$ & $\begin{array}{l}- \\
- \\
-\end{array}$ & $\begin{array}{l}- \\
- \\
-\end{array}$ & $\begin{array}{l}- \\
- \\
-\end{array}$ & $\begin{array}{l}- \\
- \\
-\end{array}$ & $\begin{array}{l}- \\
- \\
-\end{array}$ \\
\hline AB-pKT2+pBI121 & $\begin{array}{l}\text { Lineker } \\
\text { SNC } \\
\text { SNK }\end{array}$ & $\begin{array}{l}3 \\
2 \\
- \\
\end{array}$ & $\begin{array}{l}7 \\
5 \\
- \\
\end{array}$ & $\begin{array}{c}26 \\
12 \\
-\end{array}$ & $\begin{array}{c}14 \\
9 \\
- \\
\end{array}$ & $\begin{array}{l}8 \\
2 \\
- \\
\end{array}$ & $\begin{array}{c}14 \\
7 \\
-\end{array}$ & $\begin{array}{c}18 \\
1 \\
- \\
\end{array}$ & $\begin{array}{l}4 \\
- \\
-\end{array}$ & $\begin{array}{c}13 \\
1 \\
- \\
\end{array}$ & $\begin{array}{l}- \\
- \\
-\end{array}$ & $\begin{array}{l}- \\
- \\
-\end{array}$ & $\begin{array}{l}- \\
1 \\
- \\
\end{array}$ & $\begin{array}{l}- \\
2 \\
-\end{array}$ & $\begin{array}{l}- \\
- \\
-\end{array}$ & $\begin{array}{l}- \\
1 \\
-\end{array}$ & $\begin{array}{l}- \\
- \\
-\end{array}$ & $\begin{array}{l}- \\
- \\
-\end{array}$ & $\begin{array}{l}- \\
- \\
-\end{array}$ \\
\hline AB-pKT2+pSKGN1 & $\begin{array}{l}\text { Lineker } \\
\text { SNC } \\
\text { SNK }\end{array}$ & $\begin{array}{l}1 \\
1 \\
- \\
\end{array}$ & $\begin{array}{l}3 \\
- \\
-\end{array}$ & $\begin{array}{l}7 \\
2 \\
-\end{array}$ & $\begin{array}{l}5 \\
2 \\
-\end{array}$ & $\begin{array}{l}6 \\
1 \\
-\end{array}$ & $\begin{array}{l}6 \\
2 \\
-\end{array}$ & $\begin{array}{l}6 \\
1 \\
-\end{array}$ & $\begin{array}{l}4 \\
1 \\
-\end{array}$ & $\begin{array}{l}7 \\
1 \\
-\end{array}$ & $\begin{array}{l}- \\
- \\
-\end{array}$ & $\begin{array}{l}- \\
- \\
-\end{array}$ & $\begin{array}{l}- \\
- \\
-\end{array}$ & $\begin{array}{l}- \\
- \\
-\end{array}$ & $\begin{array}{l}- \\
- \\
-\end{array}$ & $\begin{array}{l}- \\
- \\
-\end{array}$ & $\begin{array}{l}- \\
- \\
-\end{array}$ & $\begin{array}{l}- \\
- \\
-\end{array}$ & $\begin{array}{l}- \\
- \\
-\end{array}$ \\
\hline
\end{tabular}

SAAT results based on SAAT performed on in vitro plant material for which optimized SAAT parameters (maximum GUS activity and explant survival) had already been determined (Teixeira da Silva and Fukai, 2002). Thus for each cultivar and for each treatment, different SAAT times were utilized. n.a. = not applicable (due to lack of material). ${ }^{t}=$ total value of all categories (leaf type expression zones) of leaf staining may exceed the total number of GUS positive plants, but each category individually can only have a maximum value equal to or less than the total number of GUS positive plants. Treatments: $C=$ Control, $A=$ Agroinfection, $B=B o m b a r d m e n t, ~ A B$ = Agrolistics (i.e. bombardment + Agroinfection), SAAT = Sonication Assisted Agrobacterium Transformation. Cultivars: SNC = Shuhouno-chikara, SNK = Shuhou-no-kokoro.

could not be observed. In SAAT treatments with pBI121, GUS expression could be observed in LIN and SNC, with a predominant GUS expression in leaf tips, leaf edges and epidermis. In pKT2-utilized SAAT treatments however, only LIN transformants could be obtained. Similar to pBI121 SAAT, GUS expression could be observed mainly in leaf tips and leaf edges, and in the epidermis. Once again, an increasing gradient of GUS expression with an increase in plantlet leaf age could be observed for both pBI121 and pKT2. Transformants could only be obtained for LIN and SNC in both pBI121 and pKT2 Agroinfected treatments (whether microprojectiles were coated with plasmid, or not). As in above treatments, an increasing gradient of GUS expression with an increase in plantlet leaf age could be observed in all Agrolistics-derived transformants. High GUS expression could be found in the leaf-tip, veins, mid-ribs, leaf edges and epidermis (Figure 1).

\section{DISCUSSION}

The initial step for the successful transformation of $D$. grandiflora is attributed to a successful tissue culture and organogenic plant regeneration system, which are affected by both explant source (in vitro or greenhouse i.e. juvenility; Table 1), cultivar and GIM used. Our results suggest that shoot regeneration and SRC, explant 
survival and qualitative callus formation (Figure $1 \mathrm{~K}, \mathrm{~L}$ ) in Dendranthema are significantly medium, cultivar and GIM-treatment dependent. In a different light, wounding (either bombardment or sonication) is both a stimulus for Agrobacterium-mediated transformation and for adventitious shoot formation (i.e. regeneration; Figure $1 \mathrm{H}, \mathrm{K}$; Bidney et al. 1992). Agroinfection decreases the $\mathrm{SRC}$ in chrysanthemum, and this is further accentuated when done in combination with particle bombardment or sonication.

As in our study, genotype dependent SRCs could be observed in D. grandiflora, ranging from $0 \%$ to $90 \%$ (Kaul et al., 1990). Similar reactions could be observed in $D$. grandiflora where a $27 \%$ SRC per explant in 'Polaris' versus $90-100 \%$ in 'Iridon' and 'Hekla' indicate genotype dependence of the regeneration protocol (Urban et al., 1994). Ironically, the only case so far reported of genotype independence of SRC was also in 'Polaris', 'Hekla' and 'Iridion' (Sherman et al., 1998).

A high number of normal shoots in Agroinfected in vitro tTCLs suggests that $A$. tumefaciens inhibits adventitious shoot formation in a cultivar-independent manner, when on a non-selective medium (Table 1), but when on a selective medium results in a significant increase in the $\mathrm{SRC}$ as a result of the regeneration of transformed cells that survive kanamycin selection. Sonication increases the SRC in in vitro SNC and SNK when used individually, but negatively impacts it when used together with Agrobacterium, while SAAT significantly decreases the SRC in in vitro LIN (Table 1). The reaction of all genotypes' greenhouse explants to SAAT was variable. A. tumefaciens LBA4404 was also shown to decrease the average number of shoots ( 0.44 per leaf piece) when on a $10 \mathrm{mg} / \mathrm{l}$ kanamycin selection medium, and the SRC was shown to be plasmid-type dependent (Ledger et al., 1991). A. tumefaciens LBA4404 was shown to drastically decrease the SRC (0-0.8 shoots per explant) in leafinfected $D$. grandiflora 'Parliament' experiments (de Jong et al., 1993), but could be slightly recovered (0.6-2.2 shoots per explant versus 2.0-4.8 in controls) when explants were pre-cultured for $8 \mathrm{~d}$ prior to Agroinfection. A pre-culture period exceeding $6 \mathrm{~d}$ in LIN or 7-8 $d$ in SNC and SNK resulted in high escape or chimeric shoot formation. LBA4404 and C58 were also shown to reduce the SRC of $D$. grandiflora to $8.5 \%$ and $7.3 \%$ of controls, respectively when on selection (15-25 $\mathrm{mg} / \mathrm{l}$ kanamycin) medium (Lowe et al., 1993). Similarly the SRC was reduced from 1.53 to 0.8 shoots per leaf explant in 'Peach Margaret' Agrobacterium-mediated transformation experiments (Boase et al., 1998), while shoot regeneration was severely hampered by the presence of kanamycin, and SRC was negatively impacted by $A$. tumefaciens LBA4404 infection in 23 Japanese $D$. grandiflora cultivars (Takatsu et al., 1998). Contrastingly, the use of cefotaxime does not affect SRC up to 500 $\mathrm{mg} / \mathrm{l}$, and in some cases stimulates shoot production when used at lower $(50-150 \mathrm{mg} / \mathrm{l})$ concentrations
(Teixeira da Silva and Fukai, 2001). Agroinfection was also shown to decrease the SRC of $D$. grandiflora stem and leaf explants on selective or non-selective optimized shoot regeneration medium, resulting in callus production, suggesting the pathogenic effect of the bacteria (Renou et al., 1993). A similar pathogenic effect could be observed in our study in all three cultivars, where any Agrobacterium-related treatment showed lowered numbers of normal and deformed shoots in in vitro and greenhouse explants on a non-selective medium (Table 1), with a decrease in explant survival and a large amount of callusing (Figure 2A,B). The negative impact that $A$. tumefaciens LBA4404 has on chrysanthemum SRC was noticed in transformation experiments using 'Fashion Yellow' and 'Golden Glory' cultivars, where the SRC was reduced by as much as 98\% compared control SRC (Young et al., 1998).

Agrolistics of in vitro explants surprisingly produces a low level of explant necrosis (that is $100 \%$ - ES; Figure $2 \mathrm{~A}$ ), considering the amount of physical wounding inflicted upon explants, and all cultivars produced more normal shoots than controls (Table 1), which may be as a result of the pre-culture period to which explants are exposed (3-4 d) to a non-selective medium, allowing cells to initiate division. As such, any pores made in the cell membrane, nuclear envelope and even the cell walls by the Au microparticles can heal, and are not necessarily lethal to the explant. Damage that does occur will however induce a tumorigenic response, resulting in large amounts of callus formation (Figure 1I,L), primarily in in vitro explants that are more juvenile and/or totipotent (Figure 2A,B). Damage to DNA by the bombardment process can induce DNA fragmentation and impair the developmental program of totipotent cells, resulting in callus formation (dedifferentiated program).

Tissue disruption can have a negative impact on SRC if excessive, but may also enhance shoot formation, which may aid the chance of recovery of transgenic shoots following a GIM. Selection medium negatively impacts SRC in any of the cultivar controls (Table 1), but following a GIM application, the SRC increases, most probably as a result of the regeneration in putatively transformed tissue as a result of the insertion of the nptll gene, conferring kanamycin resistance.

Wounds caused by sonication (Figure $1 \mathrm{~J}$ ) serve to not only attract Agrobacterium due to increased phenolic production (Trick and Finer, 1997), but also to increase callus formation (Figure 2A,B), and by exposing more cells to medium, an increased SRC can also be expected (Table 1).

Despite cutting (such as in explant preparation) and sonication being processes that potentially expose more competent cells (or cell layers) to Agroinfection, excessive wounding of plant material has a negative impact on explant survival in $96 \%$ of GIM treatments (Figure 1F,G, 2A,B), suggesting that GIM-wounded tissues need time to recover before selection initiation. 
However, the cells recovering from GIMs cannot compete effectively with uninjured, and thus non-transgenic, cells when grown under non-selective conditions. Exposure to a selective agent would, however, negatively affect the growth of uninjured cells thereby conferring a competitive advantage to truly transformed cells (arising from any GIM), explaining thus the low shoot number per explant for non GIM-treated controls on a $10 \mathrm{mg} / \mathrm{l}$ kanamycin medium (Figure 1G), and a higher shoot number from explants derived from any GIM treatment at the same selection level (Table 1), independent of explant source and genotype.

Wounding, caused by non-plasmid or plasmid-coated $\mathrm{Au}$ particles in bombardment, stimulates shoot formation to levels comparable and sometimes superior to controls when on optimized media (Table 1). Mechanical wounding, induced by brushing leaf explant surfaces, was shown to increase the SRC in $D$. grandiflora 'Parliament' (de Jong et al., 1993). In a genotypeindependent manner, greater levels of wounding stimulate more callus production on greenhouse explants (Figure 2B) than on in vitro tTCLs (Figure 2A). However, both the SRC of in vitro and greenhouse explants, and even that of callus formed from either, decreases significantly with an increase in tissue damage (Agrolistics $>$ bombardment $>$ Agroinfection $>$ sonication $>$ controls).

Adventitious shoots could be induced from green or white callus derived from any GIM treatment, once transferred to low light intensity, and none demonstrating somaclonal variation (confirmed by flow cytometry). In contrast, the placement of any hard, yellow callus or red callus on MSs resulted in a 0 SRC.

A $90-95 \%$ survival of acclimatized plantlets derived from any GIM-derived treatment in our study had no phenotypic changes, and flowering was normal. Even when deformed shoots were produced in vitro as a result of the GIM, modification of the medium followed by at least three subcultures resulted in plantlets that could grow and flower normally under greenhouse conditions (data not shown).

GIM affects SRC and location of transgene expression. Moreover, GIM was also shown to affect transformation efficiency in chrysanthemum (Teixeira da Silva and Fukai, 2002b). If transformation is indeed based on the introduction of a particular metabolic activity in the cells, it would be difficult to explain why is it that older in vitro leaves have a higher GUS expression than younger leaves (Table 2) of transformants since the assumption would be that cells present in youngest, apical leaves would be those undergoing the greatest amount of cell division, and thus a greater number of cells would be in the $S$ phase. Since vascular layers have young cells and active cell division, the metabolic activity would be high, resulting in greater amounts of $\beta$-glucuronidase. In both apple and tomatillo, the phloem stained GUS-positive, but not the xylem (Ko et al., 1998), due to a higher density of actively dividing cells in the former. The variation in GUS expression could also be explained by the existence of chimeras comprised of a mixture of transformed and untransformed cells. Moreover, GUS staining was stronger in the apical portion of the shoot as compared to basal stem samples. This difference may be explained by the fact that the metabolic activity of cells in the apical portion is higher than in the basal portion and thus small cells, which are present in the apical region, would be expected to stain more strongly than the larger basal cells. The opposite can be observed in our results, that is, a greater GUS activity in older, basal leaves than in young, apical leaves.

The specificity of gus expression in leaves (either young or old) and in the roots is dependent on the promoter type (Kamo and Blowers, 1999), while in tobacco, when the same promoter (CaMV-35S) was used, there was a 20- to 80 -fold higher GUS expression in leaves of young seedlings than leaves of mature plants, inconsistent with the fact that CaMV-35S expression occurs more in older tissues than in younger ones. The level of expression may also reflect shortcomings in the X-Gluc staining process such as insufficient infiltration pressure or time resulting in some zones being more strongly stained than others. Similarly in our results, the finding that there is GUS expression in all tissue types - even if in some more than others suggests that the cell cycle or the physiological status of the plant tissue is important. The epidermis of dicots, derived exclusively from the L1 layer in the meristem, would explain the occurrence of epidermal streaks. Since cells in the L2 layer can also be converted to epidermal cells, especially when the epidermal layer in the original meristem is damaged, or when there is the presence of high cytokinin levels, explaining the discontinuous streaks in transgenic plantlets (Valdez et al., 1998). The most common situation in chimeric plants appears to involve the L3 cell layer that forms the core of the midrib and the middle mesophyll layers in the central region of the leaf blade. As the leaf expands, there is a continuous dilution of L3 by cells from one or more subepidermal layers in the midrib and lamina (L2). This is the source of all the mesophyll tissue and the leaf margin. This continuous dilution of the transformed L3 layer by the nontransformed L2 layer results in the formation of irregular patterns generating leaves in chimeric plants, in which L1 and L3 involvement appears to be responsible for the transformation event.

There is a decrease in transgene activity from in vitro chrysanthemum transformants following greenhouse acclimatization, attributed to possible transgene silencing (Teixeira da Silva and Fukai, 2002b). Although not tested the GIM will affect the copy numbers of the transgene inserted into the genome, more in particle gun than in Agroinfection, resulting in possible gene silencing in the former. 


\section{ACKNOWLEDGEMENTS}

We thank the Japanese Ministry of Education, Science, Culture and Technology (Monbukagakusho) for a scholarship to JATdS. Kind thanks to Kirin Breweries, Inc., Japan for providing plasmid constructs.

\section{REFERENCES}

Bidney D, Scelonge C, Martich J, Burrus M, Sims L, Huffman G (1992). Microprojectile bombardment of plant tissues increases transformation frequency by Agrobacterium tumefaciens. Plant Mol. Biol. 18:301-313.

Boase MR, Bradley JM, Borst NK (1998). Genetic transformation mediated by Agrobacterium tumefaciens of florists' chrysanthemum (Dendranthema X grandiflorum) cultivar 'Peach Margaret'. In Vitro Cell. Dev. Biol. - Plant 34:46-51.

Brooks DW (2003). http://chemmovies.unl.edu/Chemistry/Biotech/A27c. html.

de Jong J, Rademaker W, van Wordragen MF (1993). Restoring adventitious shoot formation on chrysanthemum leaf explants following cocultivation with Agrobacterium tumefaciens. Plant Cell Tiss. Org. Cult. 32:263-270.

Hoekema A, Hirsch P, Hooykaas P, Schilperoort R (1983). A binary vector strategy based on the separation of the vir and T-DNA regions of the Agrobacterium tumefaciens Ti-plasmid. Nature 303:179-180.

International Labour Organization, ILO (1998). The world cut flower industry: trends and perspectives, Sect. Activities Progr. 1-10.

Jefferson RA, Kavanagh TA, Bevan MW (1987). GUS fusions: $\beta$ glucuronidase as a sensitive and versatile gene fusion marker in higher plants. EMBO J. 6:3901-3907.

Kamo K, Blowers A (1999). Tissue specificity and expression level of gus under ro/D, mannopine synthase and translation elongation factor 1 subunit a promoters in transgenic Gladiolus plants. Plant Cell Rep. 18:809-815.

Kaul V, Miller RM, Hutchinson JF, Richards D (1990). Shoot regeneration from stem and leaf explants of Dendranthema grandiflora Tzvelev (syn. Chrysanthemum morifolium Ramat.). Plant Cell Tiss. Org. Cult. 21:21-30.

Ko K, Brown SK, Norelli JL, Aldwinckle HS (1998). Alterations in nptII and gus expression following micropropagation of transgenic M7 apple rootstock lines. J. Amer. Soc. Hort. Sci. 123:11-18.

Larkin PJ, Scowcroft WR (1981). Somaclonal variation - a novel source of variability from cell cultures for plant improvement. Theor. Appl. Genet. 60:197-214.

Ledger SE, Deroles SC, Given NK (1991). Regeneration and Agrobacterium-mediated transformation of chrysanthemum. Plant Cell Rep. 10:195-199.

Lowe JM, Davey MR, Power JB, Blundy KS (1993). A study of some factors affecting Agrobacterium-transformation and plant regeneration of Dendranthema grandiflora Tzvelev (syn. Chrysanthemum morifolium Ramat.). Plant Cell Tiss. Org. Cult. 33:171-180

Mishiba K, Mii M (2000). Polysomaty analysis in diploid and tetraploid Portulaca grandiflora. Plant Sci. 156:213-219.

Murray MG, Thompson WF (1980). Rapid isolation of high molecular weight plant DNA. Nucl. Acids Res. 8:4321-4325.

Renou JP, Brochard P, Jalouzot R (1993). Recovery of transgenic chrysanthemum (Dendranthema grandiflora Tzvelev) after hygromycin resistance selection. Plant Sci. 89:185-197.

Rout GR, Das P (1997). Recent trends in the biotechnology of Chrysanthemum: A critical review. Sci. Hort. 69:239-257.

Sherman JM, Moyer JW, Daub ME (1998). A regeneration and Agrobacterium-mediated transformation system for genetically diverse chrysanthemum cultivars. J. Amer. Soc. Hort. Sci. 123:189194.

Takatsu Y, Tomotsune H, Kasumi M, Sakuma F (1998). Differences in adventitious shoot regeneration capacity among Japanese chrysanthemum (Dendranthema grandiflora (Ramat.) Kitamura) cultivars and the improved protocol for Agrobacterium-mediated genetic transformation. J. Jap. Soc. Hort. Sci. 67:958-964.

Teixeira da Silva JA, Fukai S (2001). The impact of carbenicillin, cefotaxime and vancomycin on chrysanthemum and tobacco TCL morphogenesis and Agrobacterium growth. J. Appl. Hort. 3:18-27.

Teixeira da Silva JA, Fukai S (2002a). Increasing transient and subsequent stable transgene expression in chrysanthemum (Dendranthema x grandiflora (Ramat.) Kitamura) following optimization of particle bombardment and Agroinfection parameters, Plant Biotech. 19: 229-240.

Teixeira da Silva JA, Fukai S (2002b). Change in transgene expression following transformation of chrysanthemum by four gene introduction methods, Prop. Orn. Plants 2:28-37.

Trick HN, Finer JJ (1997). Sonication-assisted Agrobacterium-mediated transformation. Transgenic Res. 6:329-337.

Urban LA, Sherman JM, Moyer JW, Daub ME (1994). High frequency shoot regeneration and Agrobacterium-mediated transformation of chrysanthemum (Dendranthema grandiflora). Plant Sci. 98:69-79.

Valdez M, Cabrera-Ponce JL, Sudhakar D, Herrera-Estrella L, Christou P (1998). Transgenic central American, west African and Asian elite rice varieties resulting from particle bombardment of foreign DNA into mature seed-derived explants utilizing three different bombardment devices. Ann. Bot. 82:795-801.

Young KJ, Jung PS, Young UB, Ho PC, Soo CY, Sheop SJ (1998). Transformation of chrysanthemum by Agrobacterium tumefaciens with three different types of vectors. J. Korean Soc. Hort. Sci. 39:360366 